Pobrane z czasopisma Annales H - Oeconomia http://oeconomia.annales.umcs.pl

Data: 26/04/2023 15:55:02

DOI:10.17951/h.2015.59.2.193

\begin{tabular}{lcl}
\hline & A N N A L E S \\
UNIVERSITATIS MARIAE CURIE-SKŁODOWSKA & LUBLIN - POLONIA \\
VOL. XLIX, 2 & SECTIOH H \\
\hline
\end{tabular}

Uniwersytet Marii Curie-Skłodowskiej w Lublinie, Katedra Finansów Publicznych

JOLANTA SZOŁNO-KOGUC

e-mail: jszolno@hektor.umcs.lublin.pl

\title{
Kształt i specyfika wydatków sektora finansów publicznych w Polsce
}

The shape and specificity of public sector expenditure in Poland

Słowa kluczowe: sektor finansów publicznych, wydatki publiczne, budżet

Keywords: public finance sector, public expenditure, budget

\section{Wstęp}

Wydatki sektora finansów publicznych mają zróżnicowaną naturę, jak i charakter. Ich permanentny wzrost wzmaga zapotrzebowanie na środki publiczne. Przy ograniczonej zasobności finansowej władz publicznych, de facto mającej swoje źródło w granicach zarówno opodatkowania, jak i zadłużania publicznego, szczególnej uwagi wymaga prawidłowość alokacji i właściwego wykorzystania środków. Tym istotniejsza staje się kwestia specyfiki wydatkowania publicznego, przejawiająca się w wielości kategorii i rodzajów wydatków publicznych, reguł ich dokonywania w różnorodnych formach prawnych i przy wykorzystaniu szerokiego spektrum instytucjonalnego (budżet państwa, budżety samorządowe, fundusze celowe). Celem niniejszego artykułu jest próba syntetycznego ujęcia zagadnienia kształtu i specyfiki wydatków publicznych z perspektywy doktryny finansów publicznych, polskiej regulacji prawnej, jak i rzeczywistej realizacji w ramach podsektora instytucji rządowych i samorządowych w Polsce. 


\section{Ekonomiczna i prawna natura wydatków publicznych}

Ekonomiczny charakter wydatków publicznych wyraża się w zużyciu części produktu krajowego brutto celem zaspokojenia wspólnych potrzeb publicznych oraz dążeń zawartych w polityce społecznej i gospodarczej państwa. Wydatki publiczne są zasadniczym elementem administracyjnego mechanizmu alokacji zasobów w gospodarce, koegzystującego z rynkowym mechanizmem alokacji zasobów w zakresie szeroko rozumianych potrzeb wspólnych [Owsiak, 2008, s. 237].

Skala i struktura wydatków publicznych ściśle uzależnione są od szeregu czynników, w których ramach należy wyróżnić: ustrój polityczny, poziom gospodarczy kraju oraz zamożność społeczeństwa. Wydatki publiczne wyrażają całokształt zagadnień ekonomicznych, finansowych, społecznych i międzynarodowych. Wskazane aspekty dotyczą w szczególności dopuszczalnych wielkości wydatków publicznych, struktury ekonomicznej, a także rodzajów i formy prawnej ich realizacji.

Aspekt ekonomiczny wydatków publicznych bezpośrednio powiązany jest ze sposobem gromadzenia środków na ich sfinansowanie. Zasadniczym sposobem pozyskiwania środków przez władze na pokrycie wydatków publicznych jest przymus administracyjny. Biorąc pod uwagę nieodzowność wydatków publicznych oraz ich pożyteczne skutki, należy zauważyć kilka indywidualnych cech realizacji środków publicznych: arbitralność regulacji odnośnie do kierunku i wielkości wydatków publicznych, zagrożenie marnotrawstwem środków publicznych, ryzyko korupcji i nadużyć oraz występowanie zjawiska „wypychania” zasobów poza obieg ściśle gospodarczy [Owsiak, 2008, s. 238].

Pierwsza cecha, dotycząca arbitralności decyzji, wiąże się bezpośrednio z administracyjnym mechanizmem rozdzielania zasobów, odpowiedzialnym za właściwe dopasowanie wydatków do zgłaszanych potrzeb publicznych. Całkowite wykluczenie zjawiska arbitralności jest nierealne, natomiast można je ograniczyć, wykorzystując obiektywne zasady realizacji środków publicznych na poszczególne cele i zadania. Mechanizm pozyskiwania środków publicznych niesie również ryzyko niegospodarności i marnotrawstwa środków publicznych. Dzieje się tak, ponieważ alokacja nie podlega kontroli ekonomicznej, co może doprowadzić do nadmiernego finansowania pewnych obszarów działalności. Funkcję rewizji w sektorze publicznym odgrywać mogą jedynie administracyjne procedury, chociaż i te, jeśli są nieodpowiednio przygotowane, niespójne wewnętrznie i nieadekwatne do realnych procesów, nierzadko również prowadzą do nieprawidłowości skutkujących niegospodarnością.

Kolejna kwestia dotyczy różnego typu nadużyć dokonywanych przy realizacji wydatków publicznych. Niebezpieczeństwo dotyczy zwłaszcza zamówień publicznych, gdy ich realizacja dokonywana jest przez podmiot, który otrzymał zlecenie, pomimo tego, że nie przedstawił najkorzystniejszych warunków wyrażających optimum ceny i jakości.

W aspekcie prawnym wydatki publiczne stanowią wykonanie funkcji, celów i zadań publicznych będących konsekwencją obowiązujących przepisów prawa, planów 
finansowych sektora publicznego oraz przyjętych programów polityki społecznej i gospodarczej państwa. $Z$ prawnego punktu widzenia istotne są następujące obszary problemowe: sposób podejmowania decyzji o tytułach i rozmiarach wydatków, formy prawne dokonywania wydatków, normatywny podział wydatków, czynności prawne realizacji wydatków oraz osoby odpowiedzialne za kondycję wydatków publicznych i ich wykonanie.

\section{Rodzaje wydatków publicznych}

Dokonując przeglądu literatury, natrafiamy na rozmaite klasyfikacje wydatków publicznych. Podziały prezentowane przez różnych autorów przenikają się wzajemnie. Na szczególną uwagę zasługuje koncepcja przyjęta przez P.M. Gaudemeta, który systematyzuje wydatki publiczne na podstawie rozbudowanego podziału w ramach czterech obszarów klasyfikacyjnych: klasyfikacji administracyjnej, politycznej, ekonomicznej oraz klasyfikacji finansowej (tab. 1).

Tabela 1. Klasyfikacje wydatków publicznych według P.M. Gaudemeta

\begin{tabular}{|c|c|c|c|}
\hline $\begin{array}{l}\text { Klasyfikacja } \\
\text { administracyjna }\end{array}$ & Klasyfikacja polityczna & Klasyfikacja ekonomiczna & $\begin{array}{l}\text { Klasyfikacja } \\
\text { finansowa }\end{array}$ \\
\hline $\begin{array}{l}\text { - według ministerstw } \\
\text { - funkcjonalne }\end{array}$ & $\begin{array}{l}\text { - neutralne } \\
\text { - aktywne } \\
\text { - według celów (polityczne, } \\
\text { społeczne, gospodarcze, inne) } \\
\text { - wg formy (wydatki na } \\
\text { świadczenie wzajemne lub } \\
\text { bez tego świadczenia, wydatki } \\
\text { definitywne i czasowe, wydatki } \\
\text { wyspecjalizowane i ogólne) }\end{array}$ & $\begin{array}{l}\text { - kapitałowe, czyli inwestycyjne } \\
\text { oraz bieżące } \\
\text { - na usługi administracyjne oraz } \\
\text { redystrybucyjne } \\
\text { - na usługi oraz transferowe } \\
\text { - klasyfikacja według ustawy } \\
\text { budżetowej } \\
\text { - klasyfikacja według reguł } \\
\text { rachunkowości }\end{array}$ & $\begin{array}{l}\text { - definitywne } \\
\text { - czasowe } \\
\text { - wirtualne }\end{array}$ \\
\hline
\end{tabular}

Źródło: P.M. Gaudemet, J. Molinier, Finanse publiczne, Warszawa 2000, s. 78-91.

Natomiast C. Kosikowski dokonuje podziału wydatków publicznych na podstawie następujących kryteriów: cele wydatków, przeznaczenie podmiotowe/przedmiotowe wydatków, charakter ekonomiczny, tytuł prawny, forma prawna, czas i wysokość (tab. 2).

Z kolei A. Wernik zawęża klasyfikację do sześciu najważniejszych kryteriów podziału: wpływ na stan majątku publicznego, powiązanie z ostatecznym wykorzystaniem produktu krajowego brutto, powtarzalność w czasie (wydatki zwyczajne oraz wydatki nadzwyczajne), wpływ na bilans płatniczy, charakter związku z zadaniami państwa oraz przeznaczenie [Wernik, 2011, s. 37]. W ramach pierwszego z wymienionych kryteriów podziału ogranicza się do wyszczególnienia wydatków majątkowych (kapitałowych) oraz wydatków bieżących. Wydatki majątkowe mają na celu powiększenie majątku publicznego, może ono następować albo w formie budowy 
Pobrane z czasopisma Annales H - Oeconomia http://oeconomia.annales.umcs.pl

Data: 26/04/2023 15:55:02

196

JOLANTA SZOŁNO-KOGUC

Tabela 2. Podział wydatków publicznych

\begin{tabular}{|l|l|}
\hline Kryterium & Rodzaje wydatków publicznych \\
\hline Cele wydatków & $\begin{array}{l}\text { Kulturalne, socjalne, edukacyjne, administracyjne, zdrowotne, gospodarcze, } \\
\text { związane z obronnością i bezpieczeństwem publicznym, ochrony środowiska, } \\
\text { obsługi długu publicznego }\end{array}$ \\
\hline $\begin{array}{l}\text { Przeznaczenie } \\
\text { przedmiotowe } \\
\text { wydatków }\end{array}$ & Inwestycyjne, bieżące \\
\hline $\begin{array}{l}\text { Przeznaczenie } \\
\text { podmiotowe wydatków }\end{array}$ & Rzeczowe, osobowe; krajowe, zagraniczne \\
\hline Charakter ekonomiczny & Odpłatne, nieodpłatne; nabywcze, redystrybucyjne, odszkodowawcze \\
\hline Tytuł prawny & Publiczny, prywatny \\
\hline Forma prawna & $\begin{array}{l}\text { Płace, zasiłki, renty, emerytury, stypendia, odszkodowania, dotacje, subwencje, } \\
\text { zapłata za roboty, dostawy i usługi }\end{array}$ \\
\hline Czas i wysokość & Stałe, zmienne; sztywne i pozostałe \\
\hline Organizacja wypłaty & Budżetowe, pozabudżetowe; państwowe i samorządowe \\
\hline
\end{tabular}

Źródło: C. Kosikowski, Prawo finansowe w Unii Europejskiej i w Polsce, LexisNexis, Warszawa 2005, s. 257.

obiektów aktywów trwałych, bądź w postaci nabycia aktywów finansowych. Kolejna klasyfikacja dotyczy związku wydatków publicznych z ostatecznym wykorzystaniem produktu krajowego brutto. W ramach tego kryterium wyróżnia się wydatki nabywcze (rzeczywiste, realne, finalne) oraz wydatki transferowe. W rezultacie wydatków nabywczych pojawia się konsumpcja składowych produktu krajowego brutto poprzez zakupy towarów i usług przez jednostki sektora publicznego. Natomiast wydatki transferowe stanowią jednostronne i nieekwiwalentne świadczenia pieniężne dla innych podmiotów najczęściej w formie dotacji, zasiłków i różnego rodzaju dopłat. Ze względu na kryterium wpływu danej kategorii wydatku na bilans płatniczy należy wyróżnić wydatki krajowe oraz wydatki zagraniczne. Wydatki zagraniczne mają ścisłe przełożenie na rachunek obrotów bieżących. Dotyczą one zarówno wydatków nabywczych, jak i transferowych.

Pod względem przeznaczenia wskazać można: wydatki socjalne, wydatki związane z realizacją podstawowych funkcji państwa, wydatki prorozwojowe oraz wydatki na obsługę długu publicznego. Wydatki socjalne wynikają bezpośrednio z realizowanej przez państwo polityki społecznej. Stanowią różnego rodzaju świadczenia pieniężne, rzeczowe, usługi oraz wydatki na działanie instytucji sektora publicznego. $\mathrm{W}$ ramach tej kategorii wydatków najistotniejsze miejsce zajmują wydatki w zakresie ubezpieczeń społecznych, zdrowotnych oraz pomocy społecznej. W polskim systemie finansów publicznych wydatki te dokonywane są w znacznym zakresie za pośrednictwem państwowych funduszy celowych (Fundusz Ubezpieczeń Społecznych, fundusze KRUS).

Państwo realizuje szereg funkcji, które zgrupować można w trzy podstawowe: klasyczne funkcje publiczne państwa, socjalne funkcje władz publicznych oraz funkcje ekonomiczne [Owsiak, 2008, s. 240]. W obszarze funkcji klasycznych wyróżniamy funkcje wewnętrzne i zewnętrzne. W ramach funkcji wewnętrznych władze 
publiczne są odpowiedzialne m.in. za utrzymanie administracji, bezpieczeństwo wewnętrzne, utrzymanie sądownictwa, natomiast sprawowanie funkcji zewnętrznych polega na zagwarantowaniu bezpieczeństwa zewnętrznego czy też na wydatkach na różnego rodzaju składki z tytułu uczestnictwa w organizacjach międzynarodowych.

W obszarze funkcji ekonomicznych warto wskazać szczególnie działania prorozwojowe, mające na celu zapewnienie niezbędnych uwarunkowań do postępu gospodarczego, a w szerszym kontekście także cywilizacyjnego państwa. W ich ramach wyróżnić można m.in. wydatki na edukację, infrastrukturę komunikacyjną i komunalną oraz badania naukowe. Obszar ekonomiczny to także wydatki na obsługę długu publicznego, dotyczą płatności odsetkowych od zaciągniętych pożyczek.

\section{Zasady dokonywania wydatków publicznych}

Zasady dokonywania wydatków publicznych rozważane na gruncie teorii [Szołno-Koguc, 2007, s. 27 i n.) znajdują mniej lub bardziej adekwatne odzwierciedlenie w regulacjach prawnych zarówno międzynarodowych, w tym unijnych [Kosikowski, 2014, s. 184 i n.], jak i krajowych. Prawo Unii Europejskiej dotyczy między innymi klasyfikacji sektora finansów publicznych według standardu ESA, rygorów dotyczących dopuszczalnych granic deficytu budżetowego i długu publicznego, unormowań oraz działań stabilizujących, podejmowanych w związku ze światowym kryzysem finansowym. Finansom publicznym został poświęcony w całości odrębny rozdział ustawy zasadniczej [art. 216-227 Konstytucji RP z dnia 2 kwietnia 1997 r.]. Regulacje dotyczące zasad gospodarowania środkami publicznymi w Polsce zawiera przede wszystkim ustawa o finansach publicznych. W szczególności cytowany akt prawny eksponuje trzy podstawowe źródła określające cele i wysokość wydatków publicznych, są nimi: ustawa budżetowa, uchwała budżetowa jednostki samorządu terytorialnego oraz plan finansowy jednostki sektora finansów publicznych [art. 44 ust. 1 ustawy z dnia 27 sierpnia 2009 r.]. Ponadto polski ustawodawca wskazuje, że wydatki realizowane przez jednostki sektora finansów publicznych dokonywane są zgodnie z przepisami, które odnoszą się do poszczególnych rodzajów wydatków [art. 44 ust. 2 ustawy]. Przedmiotowa ustawa określa również kryteria, które bezwzględnie powinny być przestrzegane przez podmioty rozporządzające publicznymi środkami finansowymi. Według tych reguł wydatki publiczne powinny być dokonywane w sposób celowy i oszczędny z uwzględnieniem zasady osiągnięcia maksymalnych efektów przy danych nakładach oraz zasady optymalnej selekcji metod i środków. Dodatkowo wydatki publiczne powinny być realizowane w sposób umożliwiający terminową realizację zadań oraz w wysokości i terminach będących skutkiem wcześniej zaciągniętych zobowiązań [art. 44 ust. 3 ustawy].

Na szczególną uwagę $\mathrm{w}$ tym kontekście zasługują zasady dokonywania wydatków publicznych o charakterze budżetowym, tj. wydatków budżetu państwa oraz wydatków budżetów samorządowych. 


\section{Formy prawne wydatków budżetu państwa}

Zgodnie z art. 112 ustawy o finansach publicznych wydatki budżetu państwa są wykorzystywane przede wszystkim na funkcjonowanie organów władzy publicznej, zadania realizowane przez administrację rządową, dotacje i subwencje ogólne dla jednostek samorządu terytorialnego, wpłaty do budżetu Unii Europejskiej, subwencje dla partii politycznych, dotacje na zadania wskazane przez inne ustawy, obsługę długu publicznego, wkład krajowy na realizację programów finansowanych z udziałem środków europejskich lub zagranicznych niepodlegających zwrotowi.

Ponadto w odniesieniu do budżetu państwa ustawa o finansach publicznych stosuje dodatkową klasyfikację wydatków budżetowych, systematyzując je w następujące grupy: dotacje i subwencje, świadczenia na rzecz osób fizycznych, wydatki bieżące jednostek budżetowych, wydatki majątkowe, wydatki na obsługę długu Skarbu Państwa, środki własne Unii Europejskiej oraz wydatki na realizację programów finansowanych z udziałem środków europejskich [art. 124 ustawy].

Należy podkreślić przy tym istotność dotacji i subwencji jako instytucji prawno-finansowych. Ich specyficzny charakter prawny przejawia się $\mathrm{w}$ tym, iż posiadają znamiona wydatków mających na celu dalszy podział na zadania dedykowane potrzebom zbiorowym, a nie jednostkowym, chociaż ich ostatecznymi adresatami są osoby fizyczne i podmioty prawne [Dębowska-Romanowska, 2010, s. 124]. Najbardziej rozbudowaną grupę wydatków stanowią dotacje. Zgodnie z art. 126 ustawy o finansach publicznych dotacje stanowią podlegające szczególnym zasadom rozliczania środki z budżetu państwa, budżetu jednostek samorządu terytorialnego oraz z państwowych funduszy celowych, przeznaczone na podstawie niniejszej ustawy, odrębnych ustaw lub umów międzynarodowych na finansowanie lub dofinansowanie realizacji zadań publicznych. Ustawodawca wyróżnia cztery rodzaje dotacji kierowanych z budżetu państwa [art. 24, 127, 130, 131 ustawy]:

1) dotacje celowe:

- na finansowanie lub dofinansowanie określonych zadań, m.in. zadań z zakresu administracji rządowej oraz innych zleconych jednostkom samorządu terytorialnego ustawami, zadań własnych jednostek samorządu terytorialnego, zadań agencji wykonawczych, zadań zleconych do realizacji organizacjom pozarządowym;

- na finansowanie lub dofinansowanie kosztów realizacji inwestycji;

- dopłaty do oprocentowanych kredytów bankowych w zakresie wskazanym w odrębnych ustawach;

2) dotacje przedmiotowe, dedykowane na dopłaty do wskazanych rodzajów wyrobów lub usług, udzielane na podstawie odrębnych ustaw lub przepisów unijnych;

3) dotacje podmiotowe, zawierające środki przeznaczane do sprecyzowanych odrębną regulacją podmiotów, wyłącznie na dofinansowanie działalności bieżącej w zakresie określonym ustawą lub umową międzynarodową, 
4) dotacje na pierwsze wyposażenie w środki obrotowe instytucji gospodarki budżetowej.

Pozostałe grupy wydatków budżetu państwa zaprezentowane zostały w poniższej tabeli.

Tabela 3. Charakterystyka wydatków budżetu państwa na podstawie ustawy z dnia 27 sierpnia 2009 r. o finansach publicznych

\begin{tabular}{|c|c|}
\hline Grupa rodzajowa & Opis \\
\hline $\begin{array}{l}\text { Wydatki bieżące jednostek } \\
\text { budżetowych }\end{array}$ & $\begin{array}{l}\text { zawierają: } \\
\text { - wynagrodzenia osób pracujących w państwowych jednostkach budżetowych; } \\
\text { - zakupy towarów, usług; } \\
\text { - koszty generowane przez jednostki budżetowe, dotyczące ich funkcjonowania } \\
\text { oraz wykonywania ich zadań; }\end{array}$ \\
\hline $\begin{array}{l}\text { Świadczenia na rzecz osób } \\
\text { fizycznych }\end{array}$ & $\begin{array}{l}\text { stanowią: } \\
\text { wydatki adresowane w sposób bezpośredni lub pośredni do osób fizycznych } \\
\text { i które nie są wynagrodzeniem za wykonywaną pracę }\end{array}$ \\
\hline $\begin{array}{l}\text { Wydatki na obsługę długu } \\
\text { Skarbu Państwa }\end{array}$ & $\begin{array}{l}\text { zawierają: } \\
\text { - wydatki z tytułu dyskonta i oprocentowania skarbowych papierów } \\
\text { wartościowych, oprocentowania zaciągniętych pożyczek, kredytów; } \\
\text { - wydatki dotyczące udzielanych gwarancji i poręczeń; } \\
\text { - koszty związane z emisją skarbowych papierów wartościowych } \\
\end{array}$ \\
\hline Wydatki majątkowe & $\begin{array}{l}\text { zawierają: } \\
\text { - wydatki na zakup, objęcie akcji oraz wniesienie udziału do spółek prawa } \\
\text { handlowego; } \\
\text { - wydatki inwestycyjne państwowych jednostek budżetowych }\end{array}$ \\
\hline $\begin{array}{l}\text { Środki własne Unii } \\
\text { Europejskiej }\end{array}$ & $\begin{array}{l}\text { obejmują: } \\
\text { - partycypację we wpływach z opłat cukrowych i rolnych, ceł; } \\
\text { - odsetki i kary za nieterminowe lub źle obliczone płatności; } \\
\text { - kwoty obliczone na bazie podatku od towarów i usług; } \\
\text { - kwoty wyliczone na bazie wysokości rocznego dochodu narodowego }\end{array}$ \\
\hline
\end{tabular}

Źródło: Opracowanie własne na podstawie: D. Biel, Prawo budżetowe, [w:] P. Antas i in., Prawo finansowe, LEX Wolters Kluwer, Warszawa 2011, oraz art. 124 ust. 2-5, art. 125 ust. 2 Ustawy z dnia 27 sierpnia 2009 r. o finansach publicznych.

\section{Formy prawne wydatków budżetów samorządowych}

Wydatki realizowane przez jednostki samorządu terytorialnego, podobnie jak te realizowane przez budżet państwa, podlegają zróżnicowanym klasyfikacjom. Jednakże mniejszy jest $w$ ich ramach udział kategorii o charakterze publicznoprawnym, ściśle normalizowanych za pośrednictwem przepisów prawa finansowego. W jednostkach samorządu terytorialnego przeważają prywatnoprawne formy wydatków, takie jak: zakupy towarów i usług, płatności z tytułu rat kapitałowych i odsetek kredytów. Zgodnie z art. 216 ustawy o finansach publicznych kierunki wydatkowania środków w ramach budżetu jednostki samorządu terytorialnego sprecyzowane są w odrębnych przepisach. W głównej mierze odnoszą się do zadań własnych jednostek samorządu terytorialnego, zadań z zakresu administracji rządowej oraz zleconych innymi ustawami, a także zadań, które zostały zaakceptowane przez jednostki samorządu terytorialnego poprzez porozumienie lub umowę, jak również 
zadań wykonywanych razem z innymi jednostkami, pomocy w formie rzeczowej lub finansowej dla innych jednostek czy programów wspófinansowanych z udziałem środków europejskich.

Zadania jednostek samorządu terytorialnego dzielą się na zadania własne (zadania obligatoryjne i pozostałe zadania własne (fakultatywne) oraz zadania zlecone, za pośrednictwem ustaw, bądź zadania wykonywane na podstawie porozumień. Środki na zadania własne pochodzą z własnych dochodów (podatki samorządowe, dochody z majątku, udziału w podatkach państwowych) oraz subwencji ogólnej. Zadania własne podlegają weryfikacji pod względem ich kompatybilności z prawem.

Natomiast zadania zlecone ustawami finansowane są za pomocą dotacji celowych, zaś zadania powierzone na mocy porozumien - zgodnie z ustaleniami zawartymi w tych porozumieniach. Zadania zlecone podlegają kontroli pod kątem następujących cech: celowość, rzetelność i gospodarność. Rozbieżny jest również sposób planowania wydatków budżetowych oraz ich wykonania. Wydatki w ramach zadań zleconych ustawami są zawarte w oddzielnym planie finansowym, stanowiącym składową budżetu jednostki samorządu terytorialnego, natomiast sprawozdanie z jego wykonania opracowywane jest oddzielnie od rocznego sprawozdania z wykonania budżetu gminy, powiatu czy województwa.

Specyficzną formą realizowania wydatków przez gminy, powiaty czy województwa są dotacje celowe. Podporządkowane są one określonym regułom. W szczególności ustawa o finansach publicznych [art. 219 ust. 1, art. 220 ust. 1, art. 221 ust. 1] przewiduje:

- dotację przedmiotową, skierowaną do samorządowych zakładów budżetowych (lub innych podmiotów w przypadku, gdy inne przepisy tak stanowią),

- dotację celową lub pomoc materialną dla innej jednostki samorządu terytorialnego,

- dotacje dla podmiotów nienależących do sektora finansów publicznych, których celem nie jest uzyskanie zysku, przekazywane na cele publiczne, dotyczące zadań tej jednostki.

Jednostki samorządu terytorialnego posiadają pewien stopień samodzielności w sferze wydatków. Samodzielność ta identyfikowana jest z posiadaną niezależnością w ramach kształtowania polityki fiskalnej, zwłaszcza odnośnie do formułowania wydatków oraz salda budżetowego. Owa samodzielność dotyczy następujących obszarów: preferowanych kierunków wydatków, struktury wydatków, reguł zaciągania zobowiązań (np. z tytułu kredytów, pożyczek), zarządzania przejętym majątkiem, kształtowania salda budżetu [Kosek-Wojnar, Surówka, 2007, s. 84].

\section{Wydatki publiczne w ujęciu podsektora rządowego i samorządowego}

Choć obowiązujące przepisy ustawy o finansach publicznych z 2009 r. nie definiują podziału sektora finansów publicznych na podsektory instytucji rządowych, samorządowych oraz ubezpieczeń społecznych, jest on wykorzystywany w zesta- 
wieniach sprawozdawczych Ministerstwa Finansów. Przy klasyfikacji poszczególnych jednostek sektora finansów publicznych do wymienionych podsektorów przyjmowane jest przyporządkowanie zgodne z metodyką unijną ESA. Tabela 4 zawiera zestawienie wydatków całego sektora finansów publicznych w podziale na trzy zasadnicze jego segmenty: podsektor rządowy, podsektor samorządowy oraz podsektor ubezpieczeń społecznych, z wyszczególnieniem przepływów wewnątrz danego podsektora oraz pomiędzy nimi (konsolidacja międzyszczeblowa).

Tabela 4. Wydatki sektora finansów publicznych (SFP) w ujęciu poszczególnych podsektorów (w miliardach złotych)

\begin{tabular}{|l|r|r|r|r|r|r|r|r|}
\hline Wyszczególnienie & 2006 & 2007 & 2008 & \multicolumn{1}{|c|}{2009} & 2010 & 2011 & 2012 & 2013 \\
\hline Ogółem SFP & 605,0 & 660,1 & 734,7 & 818,0 & 885,6 & 909,1 & 949,0 & 957,5 \\
\hline $\begin{array}{l}\text { Wydatki ogółem SFP } \\
\text { po wyeliminowaniu transferów } \\
\text { między jego elementami }\end{array}$ & 442,5 & 485,2 & 534,0 & 590,8 & 635,8 & 660,1 & 689,3 & 699,2 \\
\hline Podsektor rządowy & 265,9 & 301,2 & 330,7 & 356,1 & 397,8 & 418,2 & 445,5 & 413,6 \\
\hline $\begin{array}{l}\text { konsolidacja podsektora } \\
\text { rządowego }\end{array}$ & 22,1 & 27,1 & 30,9 & 35,4 & 22,5 & 27,5 & 29,3 & 30,6 \\
\hline Podsektor samorządowy & 157,1 & 169,0 & 189,0 & 219,0 & 226,1 & 228,7 & 230,9 & 216,8 \\
\hline $\begin{array}{l}\text { konsolidacja podsektora } \\
\text { samorządowego }\end{array}$ & 8,4 & 8,6 & 9,8 & 11,5 & 15,9 & 8,2 & 8,9 & 11,1 \\
\hline $\begin{array}{l}\text { Podsektor ubezpieczeń } \\
\text { społecznych }\end{array}$ & 182,1 & 189,8 & 214,9 & 242,9 & 261,7 & 262,2 & 272,6 & 275,0 \\
\hline $\begin{array}{l}\text { konsolidacja podsektora } \\
\text { ubezpieczeń społecznych }\end{array}$ & 3,9 & 3,9 & 4,2 & 4,3 & 15,4 & 11,7 & 10,9 & 10,4 \\
\hline konsolidacja międzyszczeblowa & 128,1 & 135,2 & 155,8 & 175,9 & 195,9 & 201,7 & 210,6 & 206,3 \\
\hline
\end{tabular}

Źródło: Opracowanie własne na podstawie sprawozdań z wykonania budżetu państwa za lata 2006-2013, dostępnych na stronie internetowej Ministerstwa Finansów (www.mf.gov.pl).

W ramach podsektora rządowego wydatki realizowane są przede wszystkim przez budżet państwa, budżet środków europejskich, instytucje gospodarki budżetowej, agencje wykonawcze, państwowe fundusze celowe oraz Narodowy Fundusz Ochrony Środowiska i Gospodarki Wodnej. Pozostałe instytucje wchodzące w skład podsektora rządowego to m.in.: PAN i tworzone przez nią jednostki organizacyjne, państwowe instytucje kultury i instytucje filmowe, samodzielne, publiczne zakłady opieki zdrowotnej, dla których organem założycielskim lub nadzorującym jest organ administracji rządowej lub inna jednostka zaliczana do podsektora rządowego, uczelnie publiczne.

Wydatki podsektora samorządowego to głównie wydatki budżetów gmin, powiatów, miast na prawach powiatu i województw (blisko $80 \%$ ogółem wydatków tego podsektora). Poza tym podsektor samorządowy obejmuje związki jednostek samorządu terytorialnego, samorządowe zakłady budżetowe, samorządowe instytucje kultury, samodzielne publiczne zakłady opieki zdrowotnej, dla których organem założycielskim lub nadzorującym jest jednostka samorządu terytorialnego, woje- 
wódzkie ośrodki doradztwa rolniczego, wojewódzkie fundusze ochrony środowiska i gospodarki wodnej, wojewódzkie ośrodki ruchu drogowego.

Podsektor ubezpieczeń społecznych tworzą takie instytucje, jak: Zakład Ubezpieczeń Społecznych i zarządzane przez niego fundusze: Fundusz Ubezpieczeń Społecznych, Fundusz Rezerwy Demograficznej, Fundusz Emerytur Pomostowych, tzw. fundusze KRUS, w tym: fundusz emerytalno-rentowy, fundusz prewencji i rehabilitacji, Fundusz Pracy oraz Narodowy Fundusz Zdrowia.

Ponad $60 \%$ wydatków sektora finansów publicznych przypada na podsektor rządowy (60\%-64\% w poszczególnych analizowanych latach). W ramach podsektora rządowego najwięcej środków przeznaczanych jest na wydatki bieżące (85\%). Instytucjonalnie, jak już wspomniano, przeważają wydatki dokonywane za pośrednictwem budżetu państwa, w którego ramach ponad połowa środków przeznaczana jest na transfery do pozostałych sektorów (subwencje i dotacje dla jednostek samorządu terytorialnego oraz dotacje dla funduszy ubezpieczeń).

\section{Zakończenie}

Specyfika wydatków publicznych przekłada się na szczególne zasady dotyczące ich kształtowania zarówno w wymiarze ekonomicznym (realizacja służąca zaspokojeniu potrzeb wspólnych przy finansowaniu ze środków publicznych), jak i prawnym (normatywny tryb ich planowania, wykonywania i kontroli). Zróżnicowany charakter i rodzaje wydatków publicznych, jak i szerokie spektrum instytucjonalne (budżet państwa, budżety samorządowe, państwowe fundusze celowe w obszarze ubezpieczeń społecznych) nie daje jasnego obrazu, nie ułatwia analiz, a przeciwnie: czyni materię niezwykle skomplikowaną, w praktyce nierzadko daleką od postulowanych reguł przejrzystości finansów publicznych. Weryfikacja zaagregowanych danych dotyczących wydatków publicznych w podziale na podsektory: rządowy, samorządowy i ubezpieczeń społecznych wskazuje na skalę transferów zarówno wewnątrz sektora, jak i pomiędzy jego elementami. Istotą wydatków publicznych jest ich redystrybucyjna rola w wymiarze całej gospodarki. Stąd ocena procesu redystrybucji wymaga nie tylko transparentności przepływów do sektora i z sektora finansów publicznych, ale także klarowności strumieni wewnątrz samego sektora, między poszczególnymi jego elementami instytucjonalnymi.

\section{Bibliografia}

1. Biel D. (2011), Prawo budżetowe, [w:] P. Antas i in., Prawo finansowe, LEX Wolters Kluwer, Warszawa. 
2. Dębowska-Romanowska T. (2010), Wydatki publiczne, ich formy prawne oraz zasady realizacji w sektorze finansów publicznych, [w:] E. Ruśkowski (red.), System prawa finansowego, tom II, Prawo finansowe sektora finansów publicznych, Wolters Kluwer, Warszawa.

3. Gaudemet P.M., Molinier J. (2000), Finanse publiczne, Warszawa.

4. Konstytucja Rzeczypospolitej Polskiej z dnia 2 kwietnia 1997 r. (Dz. U. 1997, nr 78, poz. 483 ze zm.).

5. Kosek-Wojnar M., Surówka K. (2007), Podstawy finansów samorządu terytorialnego, Wyd. Naukowe PWN, Warszawa.

6. Kosikowski C. (2014), Finanse i prawo finansowe Unii Europejskiej, Wolters Kluwer, Warszawa.

7. Kosikowski C. (2005), Prawo finansowe w Unii Europejskie i w Polsce, LexisNexis, Warszawa.

8. Owsiak S. (2008), Finanse publiczne. Teoria i praktyka, Wyd. Naukowe PWN, Warszawa.

9. Sprawozdania z wykonania budżetu państwa za lata 2006-2013, dostępne na stronie internetowej Ministerstwa Finansów (www.mf.gov.pl).

10. Szołno-Koguc J. (2007), Funkcjonowanie funduszy celowych w Polsce w świetle zasad racjonalnego gospodarowania środkami publicznymi, Wyd. UMCS, Lublin.

11. Ustawa z dnia 27 sierpnia 2009 r. o finansach publicznych (Dz. U. 2009, nr 157, poz. 1240 ze zm.).

12. Wernik A. (2011), Finanse publiczne. Cele, struktury, uwarunkowania, Wyd. Naukowe PWN, Warszawa.

\section{The shape and specificity of public sector expenditure in Poland}

The public sector expenditures vary in their nature and character. Their permanent growth increases demand for public funds. With limited financial wealth of public authorities, having its source in the range of taxation and public debt, the regularity of allocation and proper use of funds requires special attention. Some issues become therefore increasingly important and concern: the specificity of public spending, expressed in a multitude of categories and types of public expenditure, the rational rules making in a variety of legal forms, and using a broad institutional spectrum (state budget, local budgets, special funds). The purpose of this article is to synthesise the shape and characteristics of public expenditure from the perspective of the theory of public finance, legal regulations and actual implementation within the central and local government in Poland. 